\title{
Educational Application of "Nakula Edu" as Technology Construction of New Media in Building Competitive Advantages in The Covid-19 Pandemic
}

\author{
Hanif Satrio Utomo ${ }^{1}$, HenniGusfa ${ }^{2}$ \\ \{hanifsatrio15@gmail.com ${ }^{1}$,henni.gusfa@gmail.com ${ }^{2}$ \} \\ Universitas Mercu Buana, Jakarta, Indonesia ${ }^{12}$
}

\begin{abstract}
The purpose of this study is to explain technology negotiations (technology creators) with schools that provide education services for high school students in building competitive advantage during the Covid-19 pandemic. This form of research uses qualitative method, case studies by collecting data through interviews and documentation. The informants of this study were Nakula Edu product manager and management teacher of Al-Azhar school. The results of this research are negotiations carried out by IT experts in creating applications with school management objectified through school facilities, in the form of mobile applications and systems that link with schools, which become new media in student learning. Socialization is carried out with the school with parents and students. Improving the use of the application creates a comfortable learning culture with complete Nakula features. The perfection of Nakula Edu's features is based on learning needs according to the school curriculum that builds competitive advantage during the Covid 19 pandemic and the educational revolution based on industrial implementation 5.0.
\end{abstract}

Keywords: Social Construction, SCOT, Educational Application, Nakula Edu

\section{Introduction}

The corona virus or Covid-19 has spread to almost every country in the world in early 2020 since it first appeared in China. This disease has begun to attack in Europe, United States and Southeast Asia and had begun to wreak havoc in Africa and South America. Summarized from the Telegraph, the spread of the corona virus around the world likely started from a "wet market" in Wuhan, China that sold live and dead animals, including fish and birds. Such markets pose a higher risk of the virus passing from animals to humans because hygiene standards are difficult to maintain if living animals are raised and slaughtered on site. [1]

Monday (2/3), President Joko Widodo announced the first case of the corona virus in Indonesia. No half-hearted, this first case of the corona virus directly affected two Indonesian citizens. The two patients had physical contact with Japanese foreigners who came to Indonesia. "Japanese people to Indonesia visited, and they met. It turned out that the person affected by the corona virus is related to two people, a 64-year-old mother and 31-year-old daughter," said Jokowi in Jakarta, Monday (2/3)[2]. 
Through the Regulation of the Minister of Healthof the Republic of Indonesia Number 9 of 2020, a number of regulations related to the implementation of Large-Scale Social Restrictions were stipulated, one of which was regarding school holidays. Teaching and learning activities in schools have been temporarily suspended and replaced with effective media, at least for the next 14 days. Before the Large-Scale Social Restriction was approved, a number of schools had already started teaching and studying from home as an effort to reduce the spread of COVID-19. The learning process takes place at home and the students are assisted by their parents. A number of parents admitted that it was difficult to monitor their children's learning process at home, especially for those who also work at home. One of the parents, Anandatie Augustiasih, said that the information regarding the system of transferring teaching and learning process from school at home was not comprehensive.

Budi Trikorayanto, an education observer, said that the situation and conditions of education in the midst of the COVID-19 pandemic had opened the eyes of many people that the direction of education must be towards the education system 4.0, distance learning which is no longer tied to curriculum standards, but rather develops the interests and talents of students and liberate the learning process [3]. The previous study proves that the role of time and place within education is shifting, with opportunities for learning increasingly taking place outside the school timetable, at times of the learner's own choosing, and in new locations (Gray, 2017). Therefore, the new learning media which accommodate distance learning is needed in the pandemic era or in the future.

During the commemoration of National Education Day, SANS Group, a company group that focuses on developing infrastructure and technology, launched the Nakula Edu application. With mobile and web based, the Nakula Edu application is capable of answering various online teaching and learning needs. Having integrated with Nakula CBT Online and Nakula Cloud, Nakula Edu can be relied on not only to implement adequate distance learning with real-time monitoring, but also for system management and school management that are highly relevant to technological developments. In this case, Nakula Edu tries to solve a problem with technology, where Sans Group tries to answer a solution to this problem by providing an internet-based education system called Nakula Edu. Nakula Edu offers an android-based distance learning system which is managed by the school. This application is expected to be a breakthrough in the education system in Indonesia. The features available in Nakula Edu include student profiles, online attendance, lesson schedules, course materials, assessments, daily scores. [4]

This study aims to view and analyze an educational application as Social Construction of Technology in a pandemic like today, which requires distance learning activities. On the research background, the focus of this research is to analyze the Nakula Edu platform as a construction of new media technology to build competitive advantage in the pandemic era.

\subsection{Computer Mediated Communication (CMC) Theory}

In the era of information technology, the communication mode has been mediated by the internet and has moved rapidly towards what is called Computer-Mediated Communication (CMC). In this context, CMC is seen as the integration of computer technology with our daily lives. [5] According to John December (1997) [6], CMC is the process of humans communicating using computers and involving a person, in certain context situations, by being involved in the process of shaping the media as an objective. What CMC participants need in communicating with their communicants must involve two components, namely computers and internet networks. In the computer, there must be a certain program or 
application that allows the communicator to interact with the communicant, namely an Instant Messenger. In this era of globalization, Instant Messenger is increasing. [6]

\subsection{Concept of Competitive Advantage}

The era of information technology has produced an internet-mediated communication model that begins with Computer-Mediated Communication (Thurlow, 2004), the integration of computer technology with our daily lives. According to John December (1997), CMC is the process of humans communicating using computers and involving a person, in certain context situations, by being involved in the process to shape the media as an objective. During the Covid-19 pandemic, the industry experiences a division of the red zone and the green zone, and must be resilient in undergoing a process of organizing and developing structures in order to achieve its organizational goals, vision and mission, then organizing with virtualization settings.

According to Lee (Lee, 2007, p. 9) aspects of integration, centralized domination of power, which creates the emergence of platform-based communication and content that gives rise to trust based on interpersonal relationships, with a collective cultural character, which brings leadership relationships closer, the ability to manage conflict through empowerment. This sustainable competitive advantage in engagement-oriented businesses is supported by mobile platform-based technology. By involving many people, Nakula Edu's platform and features are used to strengthen skills for teachers, parents and school management in order to build characters of students. The construction of education is the skill-based engagement of teachers, school management and parents in teaching the moral values to future generations and building an educational culture based on strengthening human resources and innovative technology.

\subsection{Social Construction of Technology Theory}

The theory of Social Construction of Technology (SCOT), was firstly introduced by Wiebe E. Bijker and Trevor J. Pinch, in 1984. Technology did not just come from a vacuum, but there were discussions, negotiations between scientists/ technologist (technology creator) with the community, so that a technology can be successfully accepted. Bijker and Pinch argue that the state of technology is like science, that is, as a social construction, its trajectory depends on many social factors and the relationships between social groups. SCOT is a shift from the traditional positivist view of technology, such as blended learning, as a deterministic artefact to a perspective that takes cognizance of the social interactions of different social groups and actors in defining what the "new" technologies are, their purposes and their capabilities (Jones \& Bissell, 2011; Giddens, 1984; Berger and Luckmann, 1966. as cited in Alnesaf, 2018).

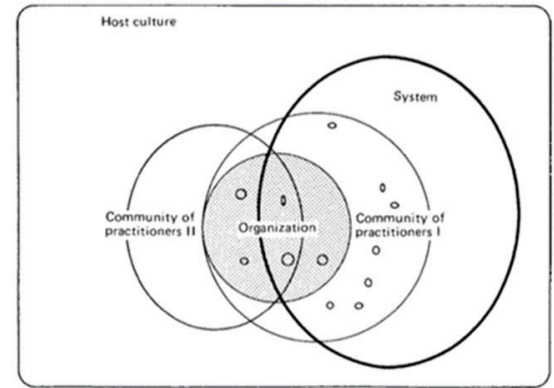

Fig 1. Community Practitioners' Relationships with New Systems and Cultures 
From the picture above, technology and practices of the education community in schools are based on technology and knowledge in carrying out learning in schools together. It does this out of the habits and connections the community has. In fact [7], both of them are inseparable, interrelated; technology and science are related and mutually benefit explicitly and implicitly. Community and knowledge embodied in the curriculum structure must be followed by the application of technology in the educational ecosystem. The dynamics of communication and learning carried out online is an organization that positions schools to be superior and trusted in the eyes of the community.

The involvement of schools, households through the role of mothers in education, involvement of students, this is associated with (Selwyn, 2006, p.110) home as a learning context for adults and application-based computers are tools used by Junior and High School students under adult control who understand the use of technology in the circulation of knowledge. So, learning at home which is applied in Indonesia is communication that changes the learning pattern from face to face using an application platform under the control of teachers, parents and the system implemented by the school.

\subsection{Family Communication Patterns Theory}

The theory of family communication pattern is widely discussed, especially during working from home situations. According to Koerner and Fitzpatrick (Jhon, 2017, p. 223), communication is an important part of the family scheme. Two orientations dominate, namely conversational orientation and conformity orientation. Families with high conversation schemes like to talk; conversely, families with low conversation schemes did not spend much time talking. Families with a high conformity scheme accept parental authority, whereas families low in this variable expect more individuality and autonomy. Each family has a certain type of parentage - defined by how they use their space, time and energy and the degree to which they express feelings, exert strength, and share in common.

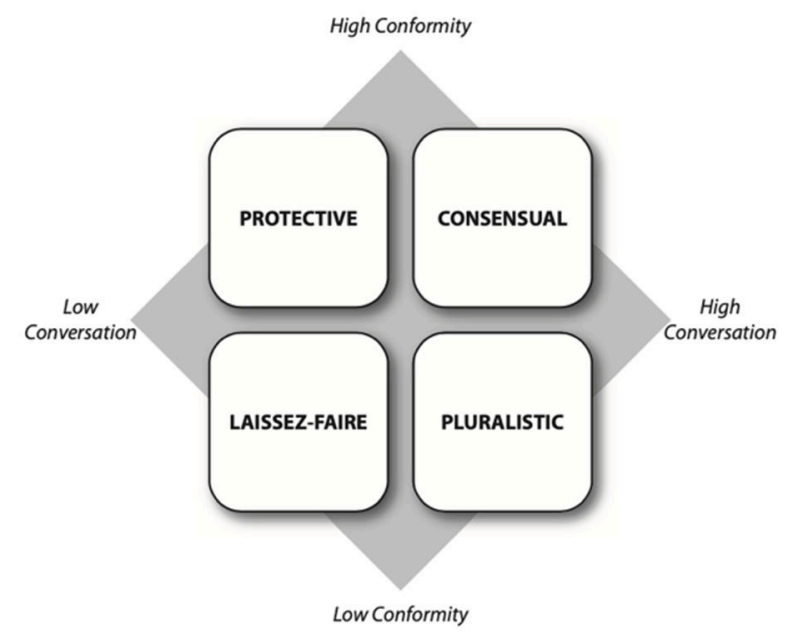

Fig 2. Family Type based on Conformity and Conversation Orientation Source: Jhon, 2017;233 


\section{Research Method}

This research paradigm is constructive and the form of qualitative research uses case studies, using interviews and documentation as data collecting method. The informants of this research are the product manager of Nakula Edu, the parents of Al-Azhar school students and an Al-Azhar school teacher. The results of the study were confirmed by using data triangulation.

\section{Results and Discussion}

Al-Azhar Syifa Budi Legenda School was established in 1997 with the levels of Play Group, Kindergarten, and Elementary School which is located at Bima Utama Raya Street, Tambun Selatan City, East Bekasi. The aim of Al-Azhar Education is to prepare Muslim intellectuals who are monotheistic, have noble character, capable and skilled, believe in themselves and are useful for religion, society and the Republic of Indonesia and are able to apply Islam and science in maintaining and enhancing the dignity of the nation. Meanwhile, his vision is to plan, organize and develop education with superior insight with a spiritualization system of education in the framework of Syifa Budi's Al Azharization pattern towards the formation of a whole human being - human beings - character and nation building. [8].

"Nakula Edu is designed to answer public concerns regarding distance learning platforms where students and teachers have to meet online with various applications during the Covid-19 pandemic. Nakula provides a one-stop solution for chatting, video calling, and e-learning in your hands so that it doesn't make it difficult. teachers and students in conducting online learning. " [9]

With mobile and web based, the "Nakula Edu" application is designed to answer various online teaching and learning needs. Integrated with Nakula CBT Online and Nakula Cloud, Nakula Edu can be relied on not only to implement online or distance learning adequately with real-time monitoring, but also for system management and school management that are highly relevant to technological developments. Features that can be accessed on the web or mobile make Nakula Edu possibly have a positive impact on student learning. This is proven by previous research that students are more likely to notice a positive impact on their learning if they use handheld mobile devices in more locations and for a greater range of learning tasks [10].

According to Fitri, the Co-Founder of the SANS Group, this integrated application was an option to be developed because he saw that many students were confused because each teacher used different applications according to their preferences or habits.

"This application offers an integrated educational solution to ensure the teaching and learning program continues optimally." [11]

As educators begin to understand the potential of mobile learning in education, the role of teachers and teacher educators in integrating mobile devices becomes essential in addressing students' learning needs across several disciplines. [12] Based on a survey by the Indonesian Child Protection Commission of 1,700 students from various levels of education on April 1320, 2020, around 76.7 percent of them admitted that they were not happy to participate in Distance Learning. Only 23.3 percent of respondents thought PJJ was impressive. Retno Listyarti, the commissioner, in a virtual press conference, Monday (27/4/2020), in Jakarta, 
said the reasons for students not being happy with distance learning were various. As many as 81.8 percent of respondents admitted that the four-week of distance learning was only given assignments by the teacher, even though there was rarely any explanation of the material and discussion. This was also conveyed to one of the students, where the interactive roles of teachers and students need to be built. [13]

"My child is an introvert person. He is more comfortable with himself. He sometimes feels unable to interact with other people, so that is necessary from the school of character, social, and morally able to interact with other people. " [14]

In a previous research that discuss about self-regulation, when learners have possibilities of participating more actively in the process of learning, as they have the freedom to make decisions about some of its aspects. The results of this study seem to confirm that selfcontrolled practice can satisfy the different characteristics and needs of extrovert and introvert learners and that they benefit individuals with different personality traits in the same way [15]. In an interview with the product manager, Nakula Edu was seen to have advantages compared to competitors, where there is an interaction between teachers and students because the material is uploaded by the teacher himself.

"There are so many educational applications that support online learning but Nakula Edu has another concept where the teacher is the teacher himself. Our strength is that we try to facilitate easier interaction between teachers and students. " [9]

Previous study is to found the relationships between communication management indicators, namely, communication practices, communication tools, and students' cognitive engagement in distance learning programs, and the result is effective communication practices and communication tools have strong positive influence on distance students' cognitive engagement [16]. These advantages make Nakula Edu able to provide interaction between teachers and students and even parents because teachers can input the learning materials easily. This can be a solution to the problems found in previous studies. In previous study, it was found that preservice teachers expressed concerns about the quality of the teacher-family relationship, meeting children's basic needs in school, and the role of parents in education [17].

"Students only need to download the Nakula Edu application on the Play Store, the teacher will be given access via the web base to fill in learning content on Nakula Edu. The features in Nakula Edu itself have been adapted to the learning mechanism in schools, including attendance, chat, video calls, subjects, assessment, grades, canteen, and invoices."

A study on measuring the extent to which students perceive stress differently during the learning process in online learning environments and traditional classrooms, the results indicated that study subjects from the traditional face-to-face classroom environment felt slightly more stressed than their counterparts taking the course online. The determinants of stress are a) finding time to study, b) accessing learning materials, c) social stress, and d) expectation from your family and friends. Considering stress problem in student, Nakula Edu Application with variative features is expected to solve the problem [18]. The Al-Azhar teachers feels that there needs to be an application that can integrate every feature that supports the teaching and learning process, such as chat, video calls, and material uploading.

"First, we used zoom and line when explaining materials with a video call, while the assignment uses google form. If the Nakula team can integrate assignment and questions, it will be very helpful"[19]. 
"The learning process that I feel is a pandemic, this is an automatic learning process, not face to face. This means that we convey to students only the essence, so by maximizing the available time given, for example, face to face which should be one week 8 times 5 is 40 hours, we only have about 20 hours. But with the expansion of the enrichment of questions given to children, through assignments it can be carried out at the time of learning or given time until the afternoon, until 3 o'clock, so usually the maximum limit is until 7 o'clock. There are still children who are not tech savvy and need assistance." [19]

Al-Azhar is a school which provides the values of the Islamic subculture, this can be seen from the results of interviews with teachers who always instill religious values in their students.

"To instill that religion, every morning I lead a pledge, then read a prayer together, when we read the Koran, we accompany the children, one student gets one verse, then there is 30 juice too, so it's quite about 30 minutes using online technology." [19].

Nakula Edu modifies the application in order that value of religious subculture could still be built in this application. This was revealed in an interview with the product manager of Nakula Edu.

"We certainly think about the religious values that exist in several schools, especially Al-Azhar which is known for its strong religious values. Here the notification function serves as a reminder of prayer schedules that will appear on the cellphone. Religious materials can also be uploaded via this application via the material feature, so that everything can be adjusted. " [9]

A paradigm shifts away from the structured, passive learning model is needed towards an interactive model where we can engage our students to become active participants in the learning process and make them knowledgeable and lifelong learners by using technology to enhance the educational process. Theology serves as a good environment to activate this paradigm shift. Therefore, remembering that it is important to pay attention to theology aspects to make a change to education [20].

In interviews with parents of students who send their students to Al-Azhar, they feel dissatisfied with the existing education system, because they are vulnerable to being exposed to adult content that is contrary to their values.

"We think the use of this line is very risky for children, to be honest we have already blocked the line on my child's cellphone, because we have seen directly on the line that there is an open chat which allows everyone to search for any group including porn or other adult content. Children are full of curiosity that can be destructive if not controlled, moreover, the temptation is right before their eyes. Not to mention that the news on the line is full of things that are not suitable for children. " [21]

According to Koerner and Fitzpatrick (Jhon, 2017, p. 223), communication is an important part of the family scheme. Two orientations is dominating, namely conversational orientation and conformity orientation. Families with high conversation schemes like to talk; conversely, families with low conversation schemes did not spend much time talking. Families with a high conformity scheme accept parental authority, whereas families low in this variable expect more individuality and autonomy.

There are 4 types of identification: (1) consensual; (2) pluralistic; (3) protective; and (4) laissez-faire. Each family has a certain type of parentage - defined by the way they use their 
space, time and energy and the degree to which they express feelings, exert strength, and share in common with their pictures:

"Most the parents are working, meanwhile children sometimes need assistance related to this technology while studying at home. " [14]

"We as parents must anticipate it properly, so that our children are not tempted, so that we realize that we have provided a better path. Moreover, it will be accounted for in the afterlife." [21]

The presence of instructors in distance education is still needed to provide motivation to learn. Teaching materials are delivered with the aim of providing understanding for the student, therefore the delivery of teaching materials in the right models and methods will greatly assist the process of understanding teaching materials. In this study there are 2 benefits that can be realized, namely theoretically, applying the convergence of learning communication theory through social media and TV, and practically providing input to lecturers, tutors, and facilitators in providing learning assistance, so that they can apply learning models according to the needs of the student. [22]. Parents support in student learning process is important. The previous longitudinal study of Korean 2nd grade middle school found that there was a positive impact of student achievement on the amount of time spent in private tutoring. [23] Another research found that student learning motivations are significantly related to both family SES and teacher-student interaction [24] . During closed school, private tutoring can be done by parent.

However, school closings during a pandemic can be a dilemma for family processes. Research on 233 parents during the H1N1 pandemic in Perth Western Australia found that almost half of parents reported missing work because of the school closure, and a third had to make special child-care arrangements [25]. Therefore, it is expected that the Nakula Edu will become a new media to solve learning problems in the COVID-19 Pandemic situation. This study is the initial stage for developing a learning communication model by using a constructivist approach based on an understanding that the development of a model can never standalone but is always accompanied by surrounding social conditions. It can be said that the learning communication model is very contextual.

The choice of the media or communication model is the result of the construction of all aspects around it. The analysis of the open university learning materials provided for a while shows that the preferred style of providing teaching material is a natural delivery style, which gives the impression not through the media. Basically, the teaching material presented is not a problem, but students need some kinds of motivator or inspiration to boost the spirit of the presence of an instructor. A variety of learning styles certainly require carefulness in processing a teaching material through the media. Media convergence is still the right choice for delivering teaching materials.

The presence of new technology and media does not come from empty space. The development of technology as a process of interaction or discourse between technologies and their relationship with social groups. According to, [26] crowdfunding utilizes technology by involving the wider community to raise funds and to run a project or business unit, with both website and application based. This allows the wider community to access (raise funds or become funders) charity programs or business projects, which drives the positive trend of philanthropy in Indonesia. The competitive advantage in virtual organizations is based on application platforms in the learning process requiring teacher capacity and students follow the users of technological features. The conversation that is carried out brings teachers, parents and students closer to achieve learning goals and closer personal relationships. 
Communication patterns that lead students are to provide direction to students and use messages of confirmation of students' understanding in the use of technology or in understanding learning materials. According to (Lee, 2007) the construct of education through technology-based learning based on teacher capacity with creativity in understanding emotional students and creative in creating material so that this expertise leads to professionalism of teachers as educators. Creation of added value is based on technology resources and the capacity of teachers and school management in building sustainable excellence.

School adaptation in the pandemic era in learning based on the Nakula Edu platform, confirms the industrial learning culture 5.0. where the al Azhar school is a place of learning based on the vision of religion and the national curriculum which adds the value of bilingual program. The creation of school excellence is not only technology-based, but also a curriculum that involves the parent community in Islamic culture. According to (Mark E. Robertson, June 2020).

Bijker and Pinch in The Social Construction of Facts and Asrtefacts: or How the Sociology and the Sociology of Technology might Benefit Each Other (1984) said that the state of technology is like science, namely as a social construction, its trajectory depends on many social factors and relationships between social groups crowd funding as a new technology and media that was born from social construction. Crowdfunding utilizes technology by involving the wider community to raise funds to help (donate) to people in need and a project or business unit that is carried out online, both website and applicationbased. This allows the wider community to access (raise funds or become funders) charity programs or business projects. Crowdfunding such as the kitabisa.com site is an example of social technology construction (SCOT) which then drives the positive trend of philanthropy in Indonesia. [26]

\section{Conclusions}

New media emerged as a result of the social construction of society in utilizing the rapid development of information technology advances in this digital era. The period of pandemic and revolution 4.0 forced education to change rapidly using distance technology. The emergence of online learning applications, such as Nakula Edu, can answer these problems. Technology does not just exist from a vacuum, but there are discussions, negotiations between scientists/ technologists (technology creators) and society, so that a technology can be successfully accepted. Nakula Edu's technology exists because of negotiations between technologists and the community, through a pandemic phenomenon.

Building sustainable excellence based on the Nakula Edu application in Al Azhar schools is also based on the competence of teachers in Islamic ethical knowledge and morals. The adaptation of social media technology and the Nakula Edu application connects learning activities and skills of teachers, students and parental monitoring. The excellence of the Al Azhar school is based on the competence of teachers to make relationships with students, and the skills to create learning materials with various methods in which they become the school's capacity to build sustainable excellence. In addition, the leadership situation in the pandemic era is based on coaching which leads teachers to be committed even in a health disaster crisis situation, but the teachers have awareness in building school excellence. 


\section{References}

[1] Rahmawati, Suara.com, "From China, This Is The Beginning Of Coronavirus Spread Around the World," 13 Mei 2020. [Online]. Available: https://www.suara.com/health/2020/04/04/183648/dari-china-begini-cara-penyebaran-viruscorona-ke-seluruh-dunia?page=all.

[2] Nuraini, Merdeka.com, "Complete story of the origin of the emergence of the corna virus in Indonesia," 3 March 2020. [Online]. Available: https://www.merdeka.com/trending/ceritalengkap-asal-mula-munculnya-virus-corona-di-indonesia.html.

[3] DW, news.detik.com, "Online Classes in the Middle of the Corona Pandemic Should Free the Learning Process," 9 April 2020. [Online]. Available: https://news.detik.com/dw/d-4971165/kelasonline-di-tengah-pandemi-corona-harusnya-memerdekakan-proses-belajar.

[4] Sans Group Website, "Sans Group Forms Nakula Edu - Solutions for Distance Education in the PSBB Era," 15 April 2020. [Online]. Available: https://www.sans-group.com/sans-groupmembentuk-nakula-edu-solusi-atas-pendidikan-jarak-jauh-dimasa-psbb/.

[5] Smith,Wood, "Online Communication: Linking Technology, Identitiy and Culture," in Online Communication: Linking Technology, Identitiy and Culture, New Jersey, Lawrence Erlbaum Associates,Inc, 2005, p. 4.

[6] C. L. L. a. T. Thurlow, "Computer Mediated Communication: Social Interaction and The Internet," SAGE Publication, p. 5, 2004.

[7] Nurwahdi, Irwansyah, "Crowdfunding as a New Media and Technology Construction," Untidar Journal, 2018.

[8] Al -Azhar Syifa Budi Legenda Website, "http://www.alazharsb-legenda.sch.id/profil/," 13 August 2020. [Online]. Available: http://www.alazharsb-legenda.sch.id/profil/.

[9] Untung, Interviewee, Interview with Product Manager. [Interview]. 10 August 2020.

[10] Cross, Sharples, Healing, \& Ellis, "Distance Learners' Use of Handheld Technologies: Mobile Learning Activity, Changing Study Habits, and the 'Place' of Anywhere Learning," International Review of Research in Open and Distributed Learning, 20(2), p. 236, 2019.

[11] Fitri, from website indonews.id, "SCOT is a shift from the traditional positivist view of technology, such as blended learning, as a deterministic artefact to a perspective that takes cognizance of the social interactions of different social groups and actors in defining what the "new" te," 0205 2020. [Online]. Available: https://indonews.id/artikel/29335/MemaknaiHardiknas-Nakula-Edu-Hadirkan-Solusi-di-Tengah-Pandemi/. [Accessed 209 2020].

[12] E. Baran, "A Review of Research on Mobile Learning in Teacher Education," Journal of Educational Technology \& Society, 17(4),, pp. 17-32, 2014.

[13] Mediana,kompas.id, "Survei KPAI: Siswa Tidak Bahagia dengan Pembelajaran Jarak Jauh, " 27 April 2020. [Online]. Available: https://kompas.id/baca/humaniora/dikbud/2020/04/27/surveikpai-siswa-tidak-bahagia-dengan-pembelajaran-jarak-jauh/. [Accessed 1510 2020].

[14] P. 2, Interviewee, Interview with parents of student school. [Interview]. 14 August 2020.

[15] Kaefer, A., Chiviacowsky, S., Meira,Cassio de Miranda,,Jr, \& Tani, G., "Self-Controlled Practice Enhances Motor Learning in Introverts and Extroverts.," Research Quarterly for Exercise and Sport, 85(2), pp. 266-33, 2014.

[16] K. K. Bakare, "Effect of communication management on distance learners' cognitive engagement in malaysian institutions of higher learning," International Review of Research in Open and 
Distributed Learning, 19(4), p. 1, 2018.

[17] Baum \& Mcmurray schwarz, "Preservice Teachers' Beliefs About Family Involvement: Implications for Teacher Education," Early Childhood Education Journal, 2004.

[18] Lazarevic, Bentz, "Student Perception of Stress in Online and Face-to-Face Learning: The Exploration of Stress Determinants," American Journal Distance Education, pp. 9-10, 2020.

[19] Farida, Interviewee, Interview with Al-Azhar Syifa Budi Legenda School Teacher. [Interview]. 13 August 2020.

[20] E. Oliver, "Digital game-based learning and technology-enhanced learning for theological education," Verbum Et Ecclesia, 39(1), p. 7, 2018.

[21] Parents1, Interviewee, Interview with parents school student. [Interview]. 13 August 2020.

[22] S. Sediyaningsih, "Konvergensi Media di Era Digital," Jurbal Pendidikan Terbuka dan Jarak Jauh 19 (1), pp. 52-57, 2018.

[23] Sohn, H., Lee, D., Jang, S., \& Kim, T. K., "Longitudinal relationship among private tutoring, student-parent conversation, and student achievement.," KEDI Journal of Educational Policy, 7(1), p. 1, 2010

[24] Liu, R., \& Yi-Lin, C, "Who is more motivated to learn? The roles of family background and teacher-student interaction in motivating student learning.," The Journal of Chinese Sociology, 6(1), 1-17, p. 13, 2019.

[25] Effer, Carcione, Giele, Dowse, Goggin, Mark, "Household Responses to Pandemic (H1N1) 2009related School Closures,Perth, Western Australia," Emerging infectious diseases [Emerg Infect Dis], ISSN: 1080-6059, 2010 Feb; Vol. 16 (2), 2010.

[26] Nathalia, Henry Brown, "Aplikasi Transportasi Online GO-JEK Bentuk dari kontruksi Sosial Teknologi dan Media Baru," Media Tor, vol. Voll 1 (2) , pp. 227-235, Desember 2018.

[27] N. Selwyn, Adult learning in the digital age, CAnada: Routledge, 2006.

[28] S. W. L. Jhon, theories of human communication, USA: waveland press, 2017.

[29] G. A. Azhar, Interviewee, Proses Belajar Mengajar Ketika Pandemi. [Interview]. 13 Agustus 2020.

[30] Andrew,Matthew, Online Communication: Linkilng Technology, Identity and Culture, New Jersey: Lawrence Erlbaum Associates, 2005.

[31] W. N. d. Irwansyah, "Crownfunding Sebagai Kontruksi Sosial Teknologi dan Media Baru". 